\title{
Risk analysis for the sustainable hydropower development in Nepal
}

\author{
Som Gurung ${ }^{1 *}$ \\ ${ }^{1 *}$ Department of Civil Engineering, Pokhara Engineering College, Pokhara, Nepal
}

\section{A R T I CLE INFO}

\section{ARTICLE HISTORY:}

Received: 15 March 2020

Revised: 11 April 2020

Accepted: 15 April 2020

Published: 30 April 2020

\section{KEYWORDS:}

Risk analysis, risk factors, hydropower, sustainable development

\begin{abstract}
A B S T R A C T
Development of hydropower projects involves a large amount of initial investment. Unlike other construction projects, hydropower projects are riskier to undertake since, the projects are large in size, linear in nature and involve many parties and stakeholders. The projects are facing cost overrun, schedule slippage, environmental, and social problems due to the various risk factors associated with the projects, which have to be identified and analysed so that the issues can be mitigated for the sustainable hydropower development in the country. This research involved identification and analysis of risk factors, which led to cost overrun and impact on the social and ecological environment due to the development of hydropower. The risk factors were identified through a questionnaire survey to the experts and literature review. The identified risks were analysed qualitatively considering both the probability of occurrence of the risk and its impact on the project and were prioritised with the help of P-I Matrix, also known as Look-Up table. The survey results revealed that the critical risk factors for the sustainable hydropower development are land acquisition problem, public disorder, adverse geological conditions, resettlement and rehabilitation, flooding, change in laws and regulations, labour disputes and strikes, and sedimentation problem. This study shall be helpful to the developers and project managers to have a better risk response plan for sustainable hydropower project development.
\end{abstract}

\section{INTRODUCTION}

Risk is inherent in every project. The chances of risk occurrence and its impacts are higher in case of large projects compared to the small development projects. The hydropower projects are no different in this context. Alternatively, hydropower projects need a large amount of investment. Effective risk analysis helps the developer to decide whether the project is safe or not for investment.

In contrast, this analysis assists the contractors in undertaking the project to control and mitigate the project risk. As a result, they could save overhead. Risk analysis is one of the crucial processes in project risk management, which assesses the risks and ultimately helps in the prioritisation of risk to have an appropriate and costeffective risk response plan. The process can proceed only after the identification of risks. Thus, identification of risks and their possible sources enable the successful risk analysis process. Mulholland and Christain (1999) highlighted that due to the complex characteristics of construction projects, the necessity of improved project risk analysis and management has increased. The primary purpose of risk analysis is to eliminate the risks before they occur or reduce the effects of risk or uncertainty, ensuring effective risk response planning. In fact, the project risk analysis and management should be cost-effective and viable. Smith et al. (2006) reported that "Risks can frequently be avoided if their root causes are identified and managed before the adverse consequence - the risk event - occurs."

Hydropower projects, which is complex in nature, large in size, and involve many parties, is subjected to numerous risks. These risks have to be identified and analysed for their sustainable development. Since hydropower development has significant impacts on the society and community economically, environmentally and socially, the environmental and social cost for resettlement requirements, modification of local land-use patterns, impacts on terrestrial and aquatic habitats should be considered (Liu et al., 2013). In Nepal, most of the hydropower projects are Run-off-River type (ROR), Storage type, and Peaking Run-off-River type (PROR). Furthermore, there are four primary river system in Nepal: (i) the Mahakali, (ii) the Karnali, (iii) the Gandaki, and (iv) the Koshi systems can offer a theoretical potential of 83,000 
MW, and economically viable potential of 42,000 MW (IBN, 2017). Despite having such vast potential, Nepal generates only $847 \mathrm{MW}$ from hydro resources, which is only $2 \%$ of economically viable potential (Alam et al., 2017). In Nepal, more than $60 \%$ of the population do not have access to national grid-connected power and even during the dry season; the power shortage becomes so high that NEA needs to ration the power up to 12 hours each day (Alam et al., 2017). Therefore, the country's immense hydropower potential needs to be utilised in broadening the market that is developing in domestic and regional areas (Tripathi and Shrestha, 2017). According to NEA Annual Report (2015), under development, large projects are Upper Tamakoshi (450 MW), Tanahu (140 MW), Rasuwagadhi (111 MW), Madhy Bhotekoshi (102 MW), Upper Trishuli 3A HEP (60 MW), Sanjen (42 MW), Upper Trishuli (42 MW), Rahughat HEP (32 MW), Chameliya HEP (30 MW), Kulekhani III (14 MW), and Upper Sanjen (14 MW). Most of these projects are facing time overrun, cost overrun, and many social and environmental implications. These risks are more significant due to the various critical risk factors associated with the project.

Therefore, the main objective of this research is to identify the critical risk factors and rank these risks for sustainable hydropower development in Nepal.

\section{METHODOLOGY}

Qualitative risk analysis method had been used for this research. This analysis process is considered as a rapid and cost-effective means of establishing priorities for making a risk response plan and acts as the foundation to perform quantitative analysis if required (PMI, 2008). The possible risks to the hydropower projects during implementation or construction phase were identified based on the literature review. Furthermore, associated risk factors were identified by conducting the questionnaire survey to the experts working in the hydropower sectors. Then, identified risks were analysed qualitatively to prioritise the risk based on which appropriate response planning can be employed for its sustainable development.

The data essential for the research were obtained from the responses of the participants as a primary source. In addition to this, the secondary source information also had been used in this research. The major secondary sources were Eustachio et al., 2019; Moran et al., 2018; Sharma, 2018; Tripathi and Shrestha, 2017; Liu et al., 2013; Chan et al., 2011; IHA, 2010; Sangroula, 2009; Panthi, 2007; Assaf and Al-Hejji, 2006; Ghosh and Jintanapakanont, 2004; Trussart et al., 2002; Akintoye and MacLeod, 1997; and Mustafa and Al-Bahar, 1991.

The criteria used to select the participants were based on the following factors:

- Working experience in hydropower sectors
- Knowledge and skills on design and construction of hydropower projects, and

- Type of organisations or institutions

The data obtained from the respondents were gathered through the questionnaire survey and analysed by using the likelihood of occurrence and impact indices. The results were shown in the findings and discussed critically. There was a total of 42 respondents. Among them, $23.81 \%$ of experts were from developers, $47.62 \%$ experts from consultants, and remaining $28.57 \%$ from contractors. The collected data were analysed both statistical and analytical approach. As suggested by PMI (2008); Gray and Larson (2008); Perez et al. (2010); and Ward (1999), the participants were requested to elicit the probability of risk and its impact based on the given guideline Table 1 and 2 .

Table 1. Rating probability of risk

\begin{tabular}{|l|l|}
\hline Likelihood & Description \\
\hline $0.90-1.00$ & Very likely to occur \\
\hline $0.70-0.80$ & Will probably occur \\
\hline $0.50-0.60$ & Equal chances of occurring or not \\
\hline $0.30-0.40$ & Probably will not occur \\
\hline $0.10-0.20$ & Very unlikely to occur \\
\hline
\end{tabular}

Table 2. Rating impact of risk

\begin{tabular}{|l|l|}
\hline Impact & Description \\
\hline 0.80 & Very high \\
\hline 0.40 & High \\
\hline 0.20 & Moderate \\
\hline 0.10 & Low \\
\hline 0.05 & Very low \\
\hline
\end{tabular}

Analysing the guideline for probability and impact rating, the author had used mean of the probability elicited by the participants since it has the highest central tendency of the data. Whereas, the author had used mode in case of impact due to the nature of the data elicited by all the participants to obtain a more accurate result. The mean for the likelihood and mode of the impact had been calculated from the statistical tool SPSS. After the selection of the value of probability and impact from the SPSS, the author had calculated risk exposure or severity applying the equation of (PMI, 2008; Gray and Larson, 2008; and Dent and Amos, 1997):

$$
\text { Risk exposure }=\text { Probability } \times \text { Impact }
$$

With the help of Eq. (1), risks are ranked or prioritised. As the value of severity is higher, then the risk is considered significant. Similarly, the risks are categorised as high, medium, and low, considering the P-I matrix. 


\section{RESULTS AND DISCUSSIONS}

During the development of the hydropower projects, risks can occur from many circumstances. Overall, nine sources of risk in hydropower project were identified and analysed. From the analysis, it was observed that the major risk factors affecting the sustainable hydropower development were S1 (Land acquisition problems), PL3 (Public disorders), C7 (Adverse geological conditions), S2 (Resettlement and rehabilitation), A2 (Flooding), PL1 (Change in laws and regulations), C4 (Labour disputes and strikes), and E7 (Sedimentation problems). These risks factors are significantly severe with higher exposure value. These risks factors have to be considered to have a proper risk response plan for optimum benefits of the project with minimal impacts on the society and the environment, which enables sustainable hydropower development in the country.

The result has shown that hydropower development projects are subjected mostly by land acquisition problems. Due to the lengthy land acquisition process and low valuation rate of the government, the probability of this risk is 0.9 that signifies there is a very high chance of occurring this risk, and its impact to the project objectives is 0.4 , which is high. Another critical risk factor is public disorder. Its likelihood of occurrence value is 0.7 , which is a high probability. It could be due to frequent obstruction of development works by the public nearby the project area for compensations, demanding more benefits such as getting more share of the projects, construction of roads and public facilities. From the analysis, it has shown that the probability of appearing of adverse geological condition risk is 0.6 , which signifies that there are equal chances of occurring it. The geology of the country is fragile due to many thrusts and folds. As a result, there is a high risk of construction of tunnels and other components of the hydropower project.

Similarly, resettlement and rehabilitation are seen as another critical risk, which likelihood of occurrence is also 0.6. The reason is that people are not willing to shift from their land as they are living there for many generations. Due to the steep terrain and heavy monsoon, there is a high chance of occurring flooding risk. The result shows that the probability of flooding occurrence is 0.5 , that means there is an equal chance of occurring this risk. The change in lows and regulations risk has appeared as another critical risk with the likelihood of 0.5 . Nepal is now in the federal governmental system. Therefore, there are chances of changing the rules and regulations regarding the right of using natural resources by the local government and central government. Since the development of a hydropower project involves a large number of labours, there are higher chances of occurring labour disputes and strikes. It has shown that it is another critical risk for the construction of a hydropower project with a value of 0.9 . Similarly, the sedimentation problem is also seen as a critical with the probability value of 0.9 for the sustainable hydropower development in Nepal.

Table 3. Risk categories for sustainable hydropower development

\begin{tabular}{|c|c|c|c|c|}
\hline $\begin{array}{l}\text { Risk } \\
\text { I.D. }\end{array}$ & Risk factors & $\begin{array}{c}\text { Risk } \\
\text { probability } \\
(\mathbf{P}) \\
\end{array}$ & $\begin{array}{c}\text { Risk } \\
\text { impact } \\
\text { (I) }\end{array}$ & $\begin{array}{c}\text { Risk } \\
\text { exposure } \\
(\mathbf{P} \times \mathbf{I}) \\
\end{array}$ \\
\hline & $\begin{array}{l}\text { Act of God } \\
\text { risk/natural } \\
\text { disaster } \\
\end{array}$ & & & \\
\hline A1 & Earthquake & 0.30 & 0.40 & 0.12 \\
\hline $\mathrm{A} 2$ & Flooding & 0.50 & 0.40 & 0.20 \\
\hline A3 & Landslide & 0.40 & 0.40 & 0.16 \\
\hline \multirow[t]{2}{*}{ A4 } & $\begin{array}{l}\text { Adverse weather } \\
\text { condition }\end{array}$ & 0.50 & 0.10 & 0.05 \\
\hline & Construction risk & & & \\
\hline C1 & $\begin{array}{l}\text { Damage to the } \\
\text { structure }\end{array}$ & 0.40 & 0.20 & 0.08 \\
\hline $\mathrm{C} 2$ & $\begin{array}{l}\text { Damage to the } \\
\text { equipment }\end{array}$ & 0.40 & 0.10 & 0.04 \\
\hline C3 & $\begin{array}{l}\text { Labour injuries and } \\
\text { accident }\end{array}$ & 0.60 & 0.20 & 0.12 \\
\hline $\mathrm{C} 4$ & $\begin{array}{l}\text { Labour disputes \& } \\
\text { strikes }\end{array}$ & 0.90 & 0.20 & 0.18 \\
\hline $\mathrm{C} 5$ & Labour availability & 0.50 & 0.20 & 0.10 \\
\hline C6 & $\begin{array}{l}\text { Construction } \\
\text { material and } \\
\text { equipment theft }\end{array}$ & 0.30 & 0.10 & 0.03 \\
\hline $\mathrm{C} 7$ & $\begin{array}{l}\text { Adverse geological } \\
\text { condition }\end{array}$ & 0.60 & 0.40 & 0.24 \\
\hline \multirow[t]{2}{*}{$\mathrm{C} 8$} & Defective works & 0.40 & 0.10 & 0.04 \\
\hline & $\begin{array}{l}\text { Contractual and } \\
\text { legal risk }\end{array}$ & & & \\
\hline CL1 & $\begin{array}{l}\text { Variation order } \\
\text { negotiation }\end{array}$ & 0.50 & 0.20 & 0.10 \\
\hline CL2 & $\begin{array}{l}\text { Delayed payment } \\
\text { on contract }\end{array}$ & 0.60 & 0.20 & 0.12 \\
\hline CL3 & $\begin{array}{l}\text { Delayed dispute } \\
\text { resolution }\end{array}$ & 0.30 & 0.10 & 0.03 \\
\hline CL4 & $\begin{array}{l}\text { Insolvency of } \\
\text { contractor or owner }\end{array}$ & 0.40 & 0.20 & 0.08 \\
\hline CL5 & $\begin{array}{l}\text { Lack of } \\
\text { enforcement of a } \\
\text { legal judgement }\end{array}$ & 0.20 & 0.10 & 0.02 \\
\hline CL6 & $\begin{array}{l}\text { Change in taxation } \\
\text { law }\end{array}$ & 0.30 & 0.20 & 0.06 \\
\hline & $\begin{array}{l}\text { Environmental } \\
\text { risk }\end{array}$ & & & \\
\hline E1 & Deforestation & 0.70 & 0.20 & 0.14 \\
\hline $\mathrm{E} 2$ & $\begin{array}{l}\text { Breaking fish fauna } \\
\text { mobility }\end{array}$ & 0.60 & 0.10 & 0.06 \\
\hline E3 & $\begin{array}{l}\text { Air pollution during } \\
\text { construction }\end{array}$ & 0.50 & 0.10 & 0.05 \\
\hline E4 & $\begin{array}{l}\text { Water quality } \\
\text { degradation }\end{array}$ & 0.50 & 0.20 & 0.10 \\
\hline E5 & $\begin{array}{l}\text { Noise pollution } \\
\text { (Blasting \& heavy } \\
\text { equipment) }\end{array}$ & 0.60 & 0.10 & 0.06 \\
\hline E6 & $\begin{array}{l}\text { Poaching of wild } \\
\text { animals }\end{array}$ & 0.40 & 0.10 & 0.04 \\
\hline
\end{tabular}




\begin{tabular}{|c|c|c|c|c|}
\hline E7 & $\begin{array}{l}\text { Sedimentation } \\
\text { problem }\end{array}$ & 0.90 & 0.20 & 0.18 \\
\hline & $\begin{array}{l}\text { Financial \& } \\
\text { Economic risk }\end{array}$ & & & \\
\hline $\mathrm{F} 1$ & Inflation & 0.40 & 0.20 & 0.08 \\
\hline $\mathrm{F} 2$ & $\begin{array}{l}\text { Fluctuation of } \\
\text { exchange rate }\end{array}$ & 0.50 & 0.20 & 0.10 \\
\hline F3 & $\begin{array}{l}\text { Fluctuation of } \\
\text { interest rate }\end{array}$ & 0.40 & 0.10 & 0.04 \\
\hline \multirow[t]{2}{*}{ F4 } & Funding & 0.30 & 0.20 & 0.06 \\
\hline & Management risk & & & \\
\hline M1 & $\begin{array}{l}\text { Change in top } \\
\text { management }\end{array}$ & 0.20 & 0.05 & 0.01 \\
\hline M2 & $\begin{array}{l}\text { Internal } \\
\text { management } \\
\text { problem }\end{array}$ & 0.30 & 0.10 & 0.03 \\
\hline M3 & $\begin{array}{l}\text { Poor relation and } \\
\text { disputes with } \\
\text { partners }\end{array}$ & 0.30 & 0.10 & 0.03 \\
\hline M4 & $\begin{array}{l}\text { No experience in a } \\
\text { similar project }\end{array}$ & 0.20 & 0.20 & 0.04 \\
\hline \multirow[t]{2}{*}{ M5 } & Teamwork & 0.10 & 0.20 & 0.02 \\
\hline & Political risk & & & \\
\hline PL1 & $\begin{array}{l}\text { Changes in law and } \\
\text { regulation }\end{array}$ & 0.50 & 0.40 & 0.20 \\
\hline PL2 & Political movements & 0.10 & 0.40 & 0.04 \\
\hline PL3 & Public disorder & 0.70 & 0.40 & 0.28 \\
\hline PL4 & $\begin{array}{l}\text { War and civil } \\
\text { disorder }\end{array}$ & 0.10 & 0.40 & 0.04 \\
\hline \multirow[t]{2}{*}{ PL5 } & $\begin{array}{l}\text { Requirements for } \\
\text { permits and their } \\
\text { approval }\end{array}$ & 0.30 & 0.10 & 0.03 \\
\hline & Social risk & & & \\
\hline S1 & $\begin{array}{l}\text { Land acquisition } \\
\text { problems }\end{array}$ & 0.90 & 0.40 & 0.36 \\
\hline S2 & $\begin{array}{l}\text { Resettlement \& } \\
\text { rehabilitation }\end{array}$ & 0.60 & 0.40 & 0.24 \\
\hline S3 & $\begin{array}{l}\text { Inundation of fertile } \\
\text { land }\end{array}$ & 0.50 & 0.20 & 0.10 \\
\hline S4 & $\begin{array}{l}\text { Inundation of } \\
\text { religious-historical } \\
\text { temple and } \\
\text { monument }\end{array}$ & 0.50 & 0.10 & 0.05 \\
\hline \multirow[t]{2}{*}{ S5 } & $\begin{array}{l}\text { Downstream } \\
\text { indigenous people } \\
\text { (Fisherman, Majhi) }\end{array}$ & 0.50 & 0.10 & 0.05 \\
\hline & Technical risk & & & \\
\hline $\mathrm{T} 1$ & Incomplete design & 0.10 & 0.20 & 0.02 \\
\hline $\mathrm{T} 2$ & Defective design & 0.40 & 0.40 & 0.16 \\
\hline $\mathrm{T} 3$ & Error and omission & 0.30 & 0.10 & 0.03 \\
\hline $\mathrm{T} 4$ & $\begin{array}{l}\text { Inadequate } \\
\text { specification }\end{array}$ & 0.30 & 0.20 & 0.06 \\
\hline T5 & $\begin{array}{l}\text { Inadequate site } \\
\text { investigation }\end{array}$ & 0.30 & 0.40 & 0.12 \\
\hline T6 & $\begin{array}{l}\text { Inadequate } \\
\text { construction } \\
\text { methodology }\end{array}$ & 0.10 & 0.20 & 0.02 \\
\hline $\mathrm{T} 7$ & $\begin{array}{l}\text { Insufficient } \\
\text { resource availability }\end{array}$ & 0.10 & 0.40 & 0.04 \\
\hline
\end{tabular}

Table 3 illustrates the risk categories for sustainable hydropower development and Table 4 presents the ranking of risk factors based on risk exposure.

Fig. 1 shows the probability-impact (P-I) matrix for rating the risk.

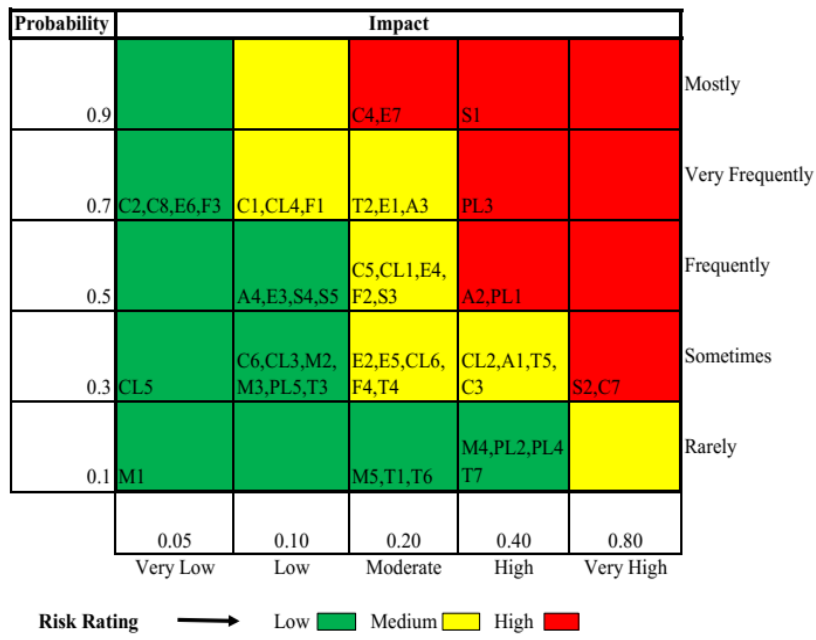

Fig. 1. Probability Impact (P-I) Matrix

Table 4. Ranking of risk factors based on risk exposure

\begin{tabular}{|l|c|}
\hline \multicolumn{1}{|c|}{ Critical risk factors } & Rank \\
\hline Land acquisition problems & 1 \\
\hline Public disorder & 2 \\
\hline Adverse geological conditions & 3 \\
\hline Resettlement and rehabilitation & 4 \\
\hline Flooding & 5 \\
\hline Change in laws and regulations & 6 \\
\hline Labour disputes and strikes & 7 \\
\hline Sedimentation problems & 8 \\
\hline
\end{tabular}

\section{CONCLUSIONS}

Hydropower projects are site-specific, complex and required a large amount of investment. Risk analysis is one of the critical risk management processes for sustainable hydropower development, which enables its optimum benefits with the minimum possible impacts to the ecological environment and society. The result revealed that social risk, construction risk, political risks, environmental risk, and the act of God risk are the most significant risk categories for sustainable hydropower development projects in Nepal. Furthermore, the critical risk factors identified for the sustainable hydropower development are land acquisition problems, public disorder, adverse geological conditions, resettlements and rehabilitation, 
flooding, change in laws and regulations, labour disputes and strikes, and sedimentation problems.

This research is helpful to the developers, funding institutions/agencies, contractors, and consultants to prepare the appropriate risk response plan for sustainable hydropower project development in Nepal. It is beyond the scope of this paper to conduct a quantitative analysis of risks for the hydropower development project, which is more precise and comprehensive.

\section{REFERENCES}

[1] Akintoye, A. S., \& MacLeod, M. J. (1997). Risk analysis and management in construction. International Journal of Project Management, 15(1), 31-38. https://doi.org/10.1016/s0263-7863(96)00035-x

[2] Alam, F., Alam, Q., Reza, S., Khurshid-ul-Alam, S. M., Saleque, K., \& Chowdhury, H. (2017). A review of hydropower projects in Nepal. Energy Procedia, 110, 581-585. https://doi.org/10.1016/j.egypro.2017.03.188

[3] Assaf, S. A., \& Al-Hejji, S. (2006). Causes of delay in large construction projects. International Journal of Project Management, 24(4), 349-357. https://doi.org/10.1016/j.ijproman.2005.11.010

[4] Chan, D. W. M., Chan, A. P. C., Lam, P. T. I., Yeung, J. F. Y., \& Chan, J. H. L. (2011). Risk ranking and analysis in target cost contracts: Empirical evidence from the construction industry. International Journal of Project Management, 29(6), 751-763. https://doi.org/10.1016/j.ijproman.2010.08.003

[5] Ghosh, S., \& Jintanapakanont, J. (2004). Identifying and assessing the critical risk factors in an underground rail project in Thailand: a factor analysis approach. International Journal of Project Management, 22(8), 633-643. https://doi.org/10.1016/j.ijproman.2004.05.004

[6] Gray, C. F., \& Larson, E. W. (2008). Project management: the managerial process. McgrawHill/Irwin.

[7] IHA. (2010). Hydropower sustainability assessment protocol. International Hydropower Association.

[8] IBN. (2017). Energy Sector Profile. Kathmandu, Nepal: Investment Board of Nepal.

[9] Liu, J., Zuo, J., Sun, Z., Zillante, G., \& Chen, X. (2013). Sustainability in hydropower development - A case study. Renewable and Sustainable Energy Reviews, 19, 230-237. https://doi.org/10.1016/j.rser.2012.11.036

[10] Moran, E. F., Lopez, M. C., Moore, N., Müller, N., \& Hyndman, D. W. (2018). Sustainable hydropower in the $21^{\text {st }}$ century. Proceedings of the National Academy of Sciences, 115(47), 11891-11898. https://doi.org/10.1073/pnas.1809426115
[11] Mulholland, B., \& Christian, J. (1999). Risk assessment in construction schedules. Journal of Construction Engineering and Management, 125(1), 8-15. https://doi.org/10.1061/(asce) 0733 9364(1999)125:1(8)

[12] Mustafa, A. (1991). Project risk assessment using the analytic hierarchy process. IEE Transactions on Engineering Management, 38(1), 46-51.

[13] NEA. (2019). A year in review- annual report fiscal year 2018/19. Kathmandu, Nepal: Nepal Electricity Authority.

[14] Panthi, K. (2007). Prioritising and estimating hydropower project construction risks: A case study of Nyadi hydropower project.

[15] Eustachio, J. H. P. P., Caldana, A. C. F., Liboni, L. B., \& Martinelli, D. P. (2019). Systemic indicator of sustainable development: Proposal and application of a framework. Journal of Cleaner Production, 241, 118383.

https://doi.org/10.1016/j.jclepro.2019.118383

[16] PMI. (2008). A Guide to project management body of knowledge. Pennsylvania, USA: Project Management Institute.

[17] Sangroula, D. P. (2009). Hydropower development and its sustainability with respect to sedimentation in Nepal. Journal of the Institute of Engineering, 7(1), 5664. https://doi.org/10.3126/jie.v7i1.2063

[18] Sharma, S., \& Kar, S. (2018). Risk management and analysis in hydro-electric projects in India. International Journal of Civil Engineering, 5(3), 1-7. https://doi.org/10.14445/23488352/ijce-v5i3p101

[19] Simon, P., Hillson, D. and Newland, K. (1997). PRAM: Project risk analysis and management guide. The Association of Project Management.

[20] Singleton, W. T. and Hovden, J. (1987). Risk and decisions. New York: John Wiley \& Sons.

[21] Smith, N. J., Merna, T. and Jobling, P. (2006). Managing Risk in Construction Projects. Blackwell.

[22] Tripathi, P., \& Shrestha, S. K. (2018). Risk assessment of boot hydropower projects in Nepal using fuzzy logic approach. Journal of Advanced College of Engineering and Management, 3, 115-125. https://doi.org/10.3126/jacem.v3i0.18965

[23] Trussart, S., Messier, D., Roquet, V., \& Aki, S. (2002). Hydropower projects: a review of most effective mitigation measures. Energy Policy, 30(14), 12511259. https://doi.org/10.1016/s0301-4215(02)00087-3

[24] Ward, S. (1999). Assessing and managing important risks. International Journal of Project Management, 17(6), 331-336. https://doi.org/10.1016/s0263-7863(98)00051-9 